\title{
Larval behavior, hydrodynamic transport, and potential offshore-to-inshore recruitment in the American lobster Homarus americanus
}

\author{
C. H. Katz ${ }^{1}$, J. S. Cobb ${ }^{1}$, M. Spaulding ${ }^{2}$ \\ ${ }^{1}$ Department of Zoology and ${ }^{2}$ Department of Ocean Engineering, University of Rhode Island, Kingston, Rhode Island 02881, \\ USA
}

\begin{abstract}
Theoretical and field patterns of offshore larval dispersal were explored for the American lobster Homarus americanus on the southern New England (USA) continental shelf. Our field collections along an offshore-inshore transect revealed a gradient of larval stages with a greater proportion of earlier stage larvae in the vicinity of offshore canyons, and more mature stage III and IV larvae domInating larval distributions closer to coastal habitats. An empirical trajectory model integrating larval behavior and hydrodynamic properties was then constructed to evaluate potential dispersal mechanisms. Model simulations suggested that passive drift via surface currents and wind-induced transport were insufficient conditions for offshore recruitment subsidies to coastal populations. In contrast, directional swimming of the fourth stage larvae resulted in successful dispersal to the coast within the duration of the planktonic phase of $H$. americanus.
\end{abstract}

KEY WORDS: Recruitment - Larval dispersal - Transport model - American lobster - Swimming behavior Surface currents . Wind-induced transport

\section{INTRODUCTION}

The demography of marine populations with complex life cycles requires an understanding not only of local adult life history traits, but of the dispersal and settlement of the planktonic larvae as well (Wallace 1876. Thorson 1950, Scheltema 1971, 1986, Underwood \& Denley 1984, Strathmann 1985, Roughgarden et al. 1988, Black \& Morgan 1991). In general, the population dynamics of these marine species are related to the integrated response of the adult and larval stages to biological and hydrodynamic factors (Phillips \& McWilliam 1986). One source of population variation lies in the growth, survival and fecundity of the adult phase. The influences of predation, competition, space, food resources, disturbances, and harvesting upon adult traits are well documented for many marine species (Connell 1961, Paine 1966, Dayton 1971, Ambrose 1984, Katz 1985, Ortega 1986, Jones 1987, Holbrock \& Schmitt 1989). The second major component of demographic variation occurs in the dispersal and colonization of the planktonic larvae (Loosanoff 1964, Scheltema 1966, Thorson 1966, Sale 1978, Keough 1983, 1984, Underwood \& Denley 1984, Gaines \&
Roughgarden 1985). In most instances, the supply of larvae is thought to originate from a number of populations within a specific region rather than result from local reproduction (Robertson 1964, Scheltema 1964, Caswell 1978, Hughes 1990). Further, larval abundances and regional as well as local ocean hydrodynamic characteristics can contribute to the dynamics of pelagic and benthic populations (Thorson 1961, Scheltema 1971, Jackson \& Strathmann 1981, Caffey 1985, Possingham \& Roughgarden 1990, Sutherland 1990). Although theoretical and empirical studies have focused on the important role of presettlement processes for over $70 \mathrm{yr}$, the specific mechanisms of larval recruitment and the variation in larval subsidies for many species remain central questions in marine population ecology and fisheries biology.

The complex process of recruitment in marine populations involves the developmental stages of the life cycle (e.g. spawning, growth, metamorphosis, survival, maturation), behavioral traits (e.g. directional swimming, vertical migration, habitat selection), and oceanographic properties (e.g. currents, wind-induced transport, tides, waves, turbulence). The role of oceanographic processes in larval dispersal (e.g. 
Scheltema 1968, Lough 1976, Epifanio et al. 1984, Johnson et al. 1984, Roughgarden et al. 1985, Bartsch et al. 1989) has received increased attention in an attempt to discern the mechanisms of recruitment and the causes of fluctuations in population dynamics Decopod and crustacean populations have been examined in an effort to integrate hydrodynamic transport with life history stages. For example, Phillips \& McWilliam (1986) showed that recruitment of the Australian rock lobster Panulirus cygnus is affected by drift due to currents as well as behavioral mechanisms such as vertical migration and responses to lunar phases. Possingham \& Roughgarden (1990) investigated theoretically the effects of coastal diffusion and advection on intertidal barnacles, and Davis (1984) modeled copepod dynamics in a simulated gyre designed to mimic the circulation on George's Bank (NW Atlantic). In each of these studies, the larvae are assumed to be passive particles or are limited to vertical migrations. Here, we investigate not only the role of oceanographic properties, but also the horizontal directional swimming behavioral traits of larvae of the American lobster Homarus americanus.

The purpose of this study was to explore the patterns and mechanisms of offshore larval dispersal in Homarus americanus, and ascertain the potential contributions from offshore recruitment to coastal populations. Specifically, our hypothesis submits that coastal lobster populations of Rhode Island and southeast Massachusetts, USA, are subsidized by larvae released in canyons near the continental slope. Our approach was to examine general larval dispersal patterns over the northeastern continental shelf, and to explore mathematically the oceanographic and behavioral mechanisms that may influence this larval dispersal. Initially, field collections were used to delineate the distribution of lobster larvae along a $150 \mathrm{~km}$ offshoreinshore transect. Next, we developed an empirical trajectory model to simulate larval movements. The model integrated surface currents, wind-induced surface transport, passive drift in the early stage lobster larvae, and directional swimming behavior of the final stage larvae. Stepwise increases in complexity of the model were used to generate offshore-onshore larval patterns. General insights from the model were used to qualitatively suggest the possible mechanisms necessary for the offshore recruitment given the constraints of the life history traits of $H$. americanus.

\section{LIFE HISTORY AND EXPERIMENTAL METHODS}

The complex life cycle of Homarus americanus consists of 4 larval stages, a juvenile benthic phase, and the mature adult. Similar to the dispersal of many other benthic invertebrate larvae, the first 3 developmental stages of the lobster drift passively with geostrophic and windforced currents. Recent evidence suggests that the first 2 stages may exhibit diel vertical migration in deeper waters (Harding et al. 1987). More interestingly, observations reveal that the fourth stage larvae (classically referred to as the postlarvae) are active directional swimmers (Ennis 1986a). Short-term field observations (Cobb et al. 1989) of the fourth stage larvae at or very near the surface indicate that individuals in this life history stage are rapid swimmers with a mean velocity of $18 \mathrm{~cm} \mathrm{~s}^{-1} \pm 0.049$ (standard error), while swimming speeds noted in laboratory-reared larvae are slightly slower at $10.7 \mathrm{~cm} \mathrm{~s}^{-1}$ (Rooney \& Cobb 1991). Furthermore, swimming is orientated in a northerly direction for a majority of larvae in the fourth stage. The average life span and, therefore, the dispersal time of the passive and swimming stages in 18 to $21^{\circ} \mathrm{C}$ waters is $26 \mathrm{~d}$ (Herrick 1909, Templeman 1936, Wilder 1953). Specifically, the development times for stages I, II, III, and IV are 3, 3, 4 , and $16 \mathrm{~d}$ respectively. Following the active dispersal phase, the stage IV larvae search for and settle in suitable sheltered habitats (Wahle \& Steneck 1991).

In 1988, an offshore-inshore transect on the southern New England (USA) continental shelf was sampled to test the hypothesis that an offshore recruitment subsidy would result in a gradient of larval stages with a corresponding greater proportion of stage IV larvae nearer to the coastal habitats. The sampling procedure consisted of a series of surface neuston tows from approximately $40.1^{\circ} \mathrm{N}, 69.4^{\circ} \mathrm{W}$ to $41.05^{\circ} \mathrm{N}, 71.6^{\circ} \mathrm{W}$. A $2 \times 2 \mathrm{~m}$ neuston net with a $1000 \mu \mathrm{m}$ mesh was used to determine abundances of lobster larvae during weekly tows between June 11 and August 16. The tows were made from a commercial lobster vessel and lasted 30 min at a speed of 2.8 to 3.0 knots. All larvae were washed into the cod-end with seawater, and the number of stage I to IV larvae was recorded for each date. A chi-square analysis was used to test the null hypothesis that the distribution of larval stages was independent of sample locations. The analysis was calculated on a Dell $38633 \mathrm{MHz}$ computer using SAS (1985, 1987) for personal computers.

\section{DISPERSAL MODEL}

A trajectory model was formulated to ascertain the relative importance of oceanographic processes and behavioral traits (e.g. swimming) on lobster larvae dispersal. The lobster larval transport model is based on an empirical hydrodynamic vector equation (see Spaulding 1988) and is denoted as:

$$
\overrightarrow{U_{L}}=\vec{U}_{\text {current }}+\vec{U}_{\text {wind-induced transport: }}+\vec{U}_{\text {swimming }}
$$

where $\vec{U}_{\mathrm{L}}$ is the resultant velocity of the larvae; $\vec{U}_{\text {current }}$ 
describes velocity of long-term mean shelf surface currents: and $\vec{U}_{\text {swimming incorporates swimming speed and }}$ direction of the fourth stage larvae, with $\vec{U}_{\text {swimming }}=0.0$ for stages I, II, and III. $\vec{U}_{\text {wind-induced transport represents the }}$ transport of surface larvae due to winds and is described as:

$$
\vec{U}_{\text {wind-induced transport }}=\overrightarrow{\lambda\left|U_{\text {wind }}\right|} \text {. }
$$

Here, $\lambda$ is a coefficient that describes the windinduced transport as some percentage of the absolute wind speed $\left(\left|U_{\text {wind }}\right|\right)$. For most objects in the upper meter of the water column, $\lambda$ is equal to between 1 and $2 \%$ of the wind speed, while objects that float at the surface (e.g. oil) move at 3 to $4 \%$ of the wind speed (Stolzenbach et al. 1977). The wind-induced transport direction is to the right of the wind in the northern hemisphere due to the Coriolis force, with an angle $\theta$ varying between 0 and $25^{\circ}$ (mean $\left.=15^{\circ}\right)$ depending on the velocity of the wind.

The continental shelf extending from $39^{\circ}$ to $42.5^{\circ} \mathrm{N}$ and $68^{\circ}$ to $75^{\circ} \mathrm{W}$ was divided into a horizontal grid with a cell size of $5 \mathrm{~km}^{2}$. The mean shelf surface currents obtained from the U.S. Naval Oceanographic Office, ocean drifter data (Bumpus \& Lauzier 1965), and current meter observations (Beardsley et al. 1976) were integrated into the model grid. Current speeds on the shelf ranged from 10 to $50 \mathrm{~cm} \mathrm{~s}^{-1}$ with a general flow to the west and southwest. The direction and speed of the wind were obtained hourly from the NOAA/National Weather Service Station at T. F. Green Airport in Warwick, Rhode Island. Observed wind direction was primarily out of the southwest in June and July 1988. Since offshore wind velocities are stronger than those measured at the land based stations, winds were compared with offshore buoys (Godshell et al. 1980, Gilhousen et al. 1983) and multiplied by a conversion factor of 2. Wind-induced transport (the coefficient $\lambda$ ) was set at either 0,1 , or $2 \%$ of the wind speed. In this model, stage I, II, and III larvae are assumed to be transported passively for $10 \mathrm{~d}$. With metamorphosis to the stage IV larvae, the vector for directional swimming was set to either $10 \mathrm{~cm} \mathrm{~s}^{-1}$ or $18 \mathrm{~cm}$ $s^{-1}$. In addition, trajectories were generated either with continuous $24 \mathrm{~h}$ swimming or with diurnal swimming from 05:00 to $19: 00 \mathrm{~h}$. Swimming ori- entation in each case was set towards magnetic north. The transport trajectories were determined by simulating the release of larvae at several locations along the canyons, and following their dispersal spatially and temporally over the continental shelf. Simulations were begun in mid-June of 1988 to coincide with the emergence of lobster larvae in the field. The model simulations were performed on a MicroVax II, and allowed to run for up to $40 \mathrm{~d}$.

A 2-way analysis of variance (TANOVA) was calculated to determine the effects of larval swimming behavior and wind-induced transport on dispersal rates. In this case, the null hypothesis was that dispersal times from the offshore to inshore habitats were equal for each fixed treatment. The model used in this 2-way analysis was $Y_{i j k}=w+\alpha_{1}+\beta_{j}+\alpha \beta_{i j}+e_{i j k}$, where $Y$ is the variation in dispersal, $w$ is the overall mean, $\alpha$ is the effects of larval swimming behavior, $\beta$ is the impact of wind-induced transport, $\alpha \beta$ is the interaction term, and $e$ is the random deviation of the individual $k$ samples from the $i$ th and $j$ th group. A priori comparisons of swimming speeds and duration were performed with orthogonal contrasts. These statistics were generated using the SAS (1985) GLM procedure.

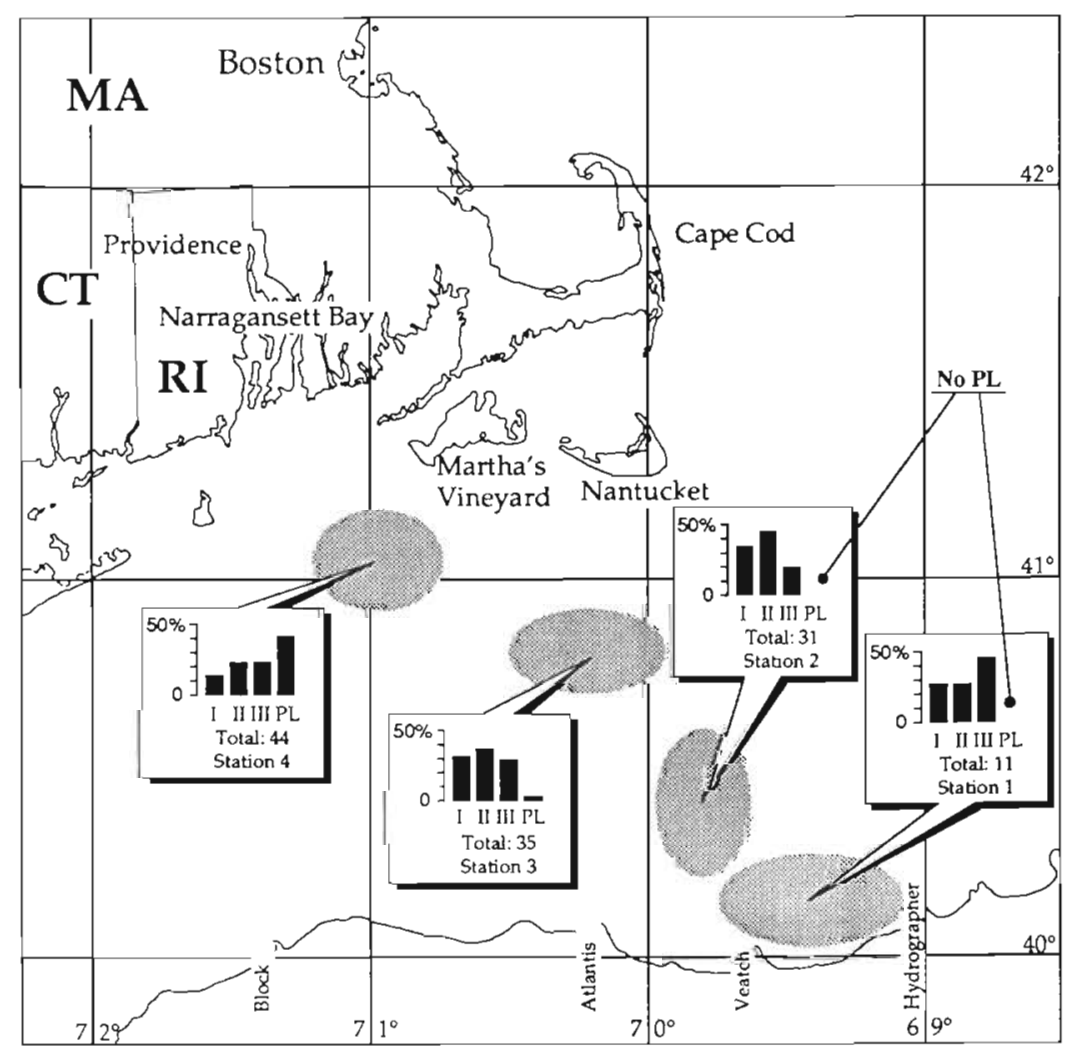

Fig. 1. Homarus americanus. Inshore-offshore transect showing the percent of lobsters in each larval stage at 4 locations off the New England (USA) coast. PL: postlarvae; Block, Atlantis, Veatch, Hydrographer: canyons in the continental slope 


\section{Surface Currents}

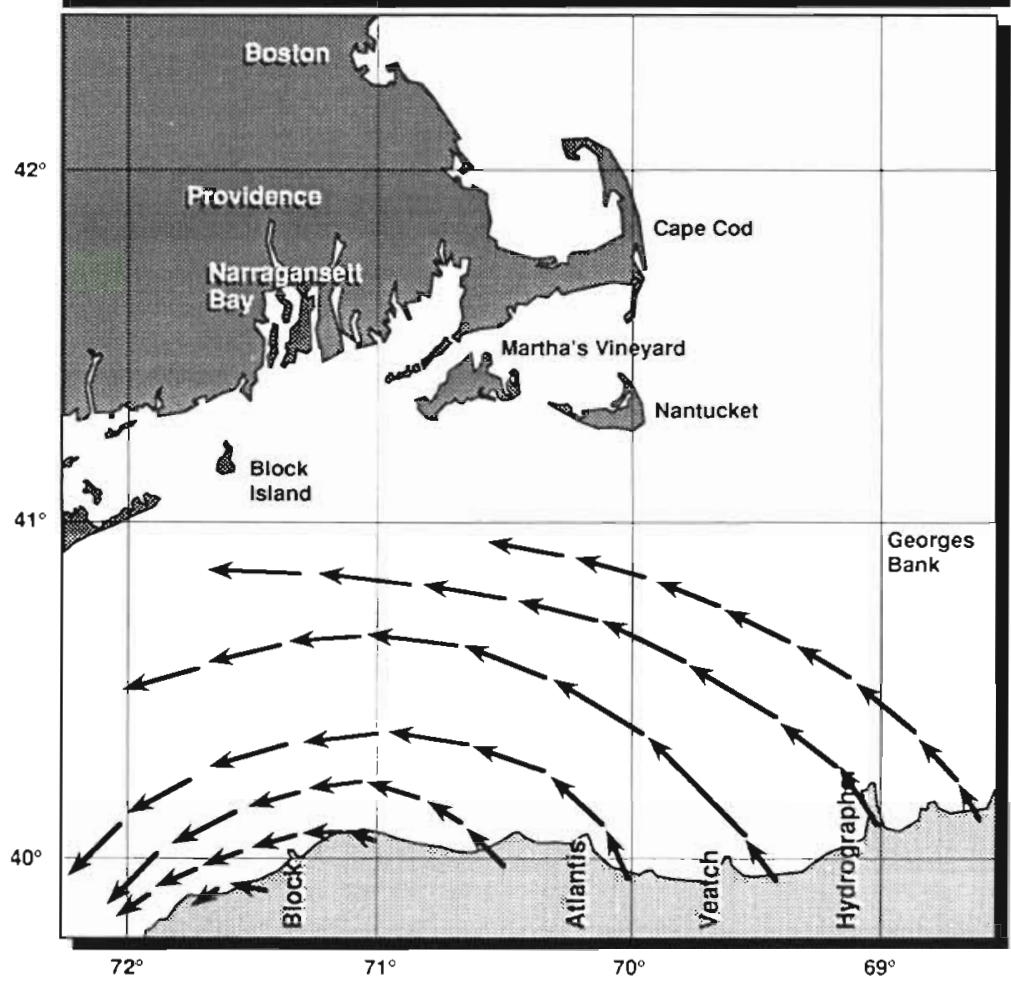

Fig. 2. Simulated passive dispersal of larvae of American lobster Homarus americanus, as influenced by surface currents. Dispersal trajectories are represented by arrows whose orientation indicates direction, and length denotes distance traveled over a 5 d interval

of the samples consisting of stage I larvae. Comparison of the number of individuals per stage revealed a significant difference in the larval distributions for the 4 areas (chi-square, $\mathrm{p}<0.05$ ).

In an effort to distinguish the relative potential effects of physical and biological mechanisms on dispersal rates, larval trajectories were first modeled with only the influence of surface currents, then as a vector sum of currents and wind-inducted transport, and finally as a vector sum of current, wind, and swimming. Initially, dispersal as a simple function of surface currents resulted in a southwest recruitment pattern over the continental shelf after a $40 \mathrm{~d}$ simulation (Fig. 2). Note that each arrow indicates the simulated dis-

RESULTS

The field distribution of the 4 larval stages showed a distinct pattern along the offshore-inshore transect (Fig. 1). In general, the transect showed a greater proportion of the earlier stage larvae in offshore waters, while the stage IV larvae predominated closer to the coast. At Stns 1 and 2 near the canyons, stage I, II, and III larvae comprised $100 \%$ of the larval abundances. For example, stages I and II were observed to constitute $35 \%$ and $45 \%$ of the total samples respectively at Stn 2 , and the remaining $19 \%$ were stage III individuals. The intermediate sampling site (Stn 3) revealed a relatively even distribution of stage I, II and III, and the first evidence of stage IV larvae ( $3 \%$ ) in the water column. Conversely, Stn 4 was dominated by the fourth stage larvae at $41 \%$ with only $14 \%$

Fig. 3. Simulated dispersal of Homarus americanus larvae as affected by currents and 1\% wind-induced transport. Arrows as in Fig. 2. except that arrows contacting the islands or mainland describe distances covered in $\leq 5 \mathrm{~d}$

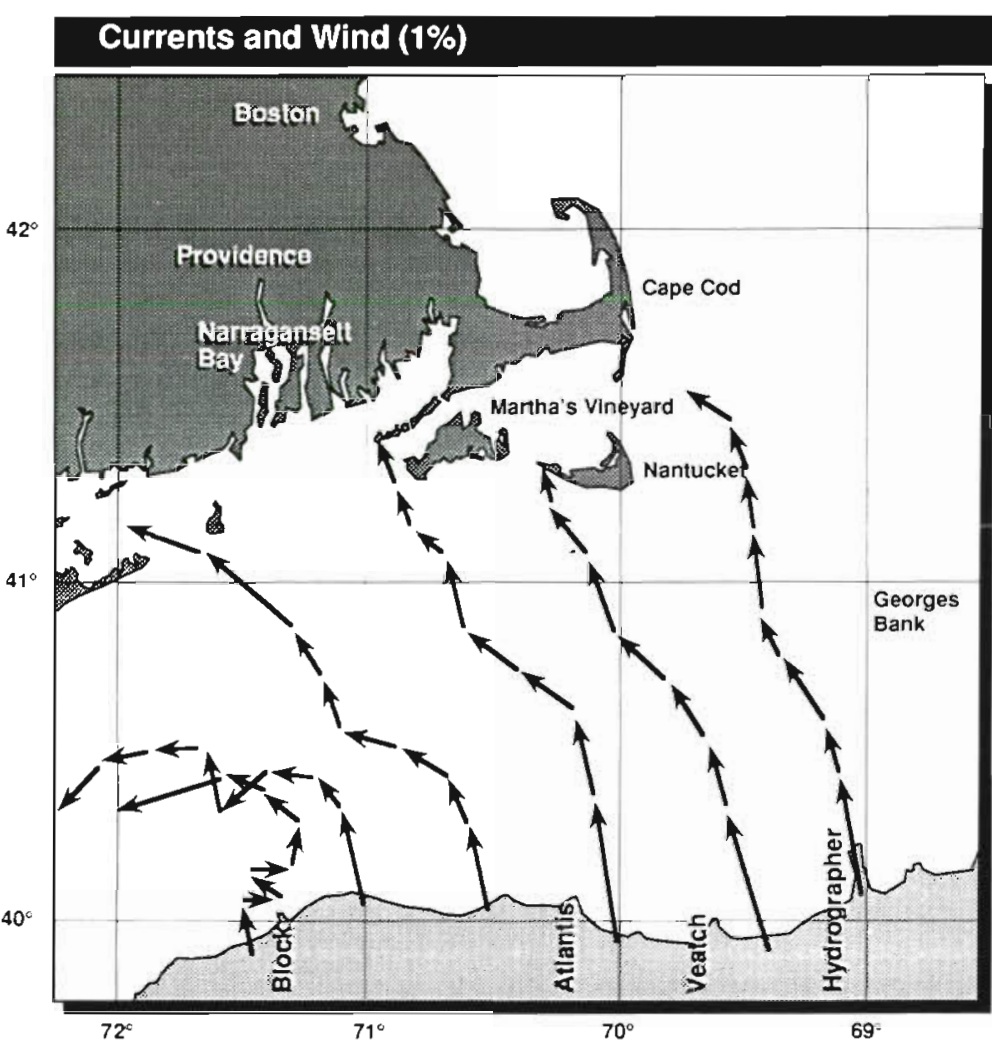




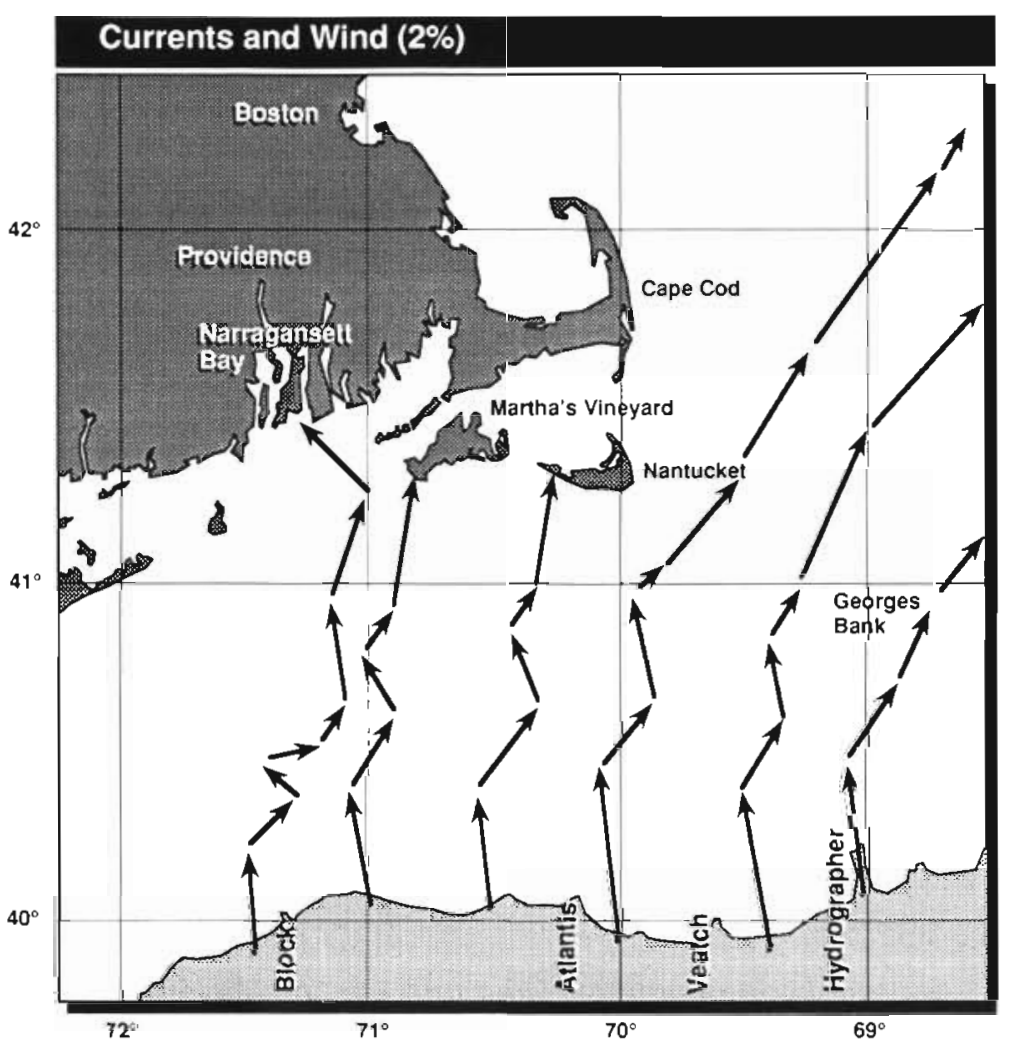

Fig. 4. Theoretical trajectories indicating Homarus americanus larval movement due to currents and $2 \%$ wind-induced transport. Arrows as in Fig. 3

tance traveled by the larvae for $5 \mathrm{~d}$ intervals, and that the closest larvae remained approximately $45 \mathrm{~km}$ offshore. Given a mean planktonic duration of $26 \mathrm{~d}$, passive drift appears to be an insufficient mechanism for coastal subsidies. Further, we would expect these larvae to begin settling and colonizing suitable habitats between the canyons and coasts. Next, incorporating $1 \%$ wind-induced transport with mean currents, the larvae are shown to drift into the vicinity of Martha's Vineyard, Nantucket Island, and Block Island after $40 \mathrm{~d}$ (Fig. 3). In this instance, recruitment to the islands would occur if settlement were delayed for approximately 15 d. At $2 \%$ wind-induced transport, trajectories shifted to the northeast (Fig. 4) as a consequence of southwesterly winds typical of the summer months in this region, and with higher wind-induc-

Table 1. Mean simulated dispersal times of Homarus americanus larvae, in days, from the offshore canyons to coastal habitats as related to surface currents, wind-induced transport, and postlarval swimming. The means and standard errors were calculated from those trajectories that intersect islands or the mainland of the states of New York, Connecticut, Rhode Island, and Massachusetts, USA

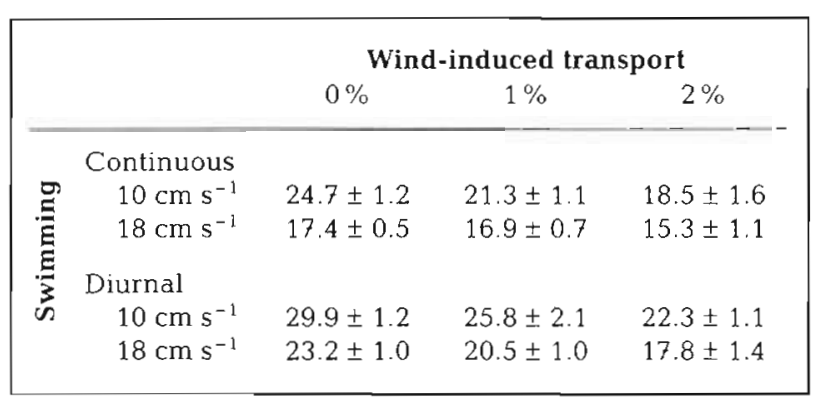

tion the larvae were blown away from the coast and towards George's Bank.

Integrating directional swimming of the stage IV larvae and the hydrodynamic properties (Table 1) had a significant effect on dispersal times (Table 2; TANOVA, $p<0.01$ ) and general patterns of movement. Orthogonal contrasts revealed notable differences in dispersal times to the coast between diurnal and continuous swimming behavior at $18 \mathrm{~cm} \mathrm{~s}^{-1}(\mathrm{p}<0.01)$, and diurnal $10 \mathrm{~cm} \mathrm{~s}^{-1}$ and continuous $18 \mathrm{~cm} \mathrm{~s}^{-1}$ dispersal $(p<0.01)$. Conversely, dispersal was similar $(p=0.33)$ for stage IV larvae simulating continuous $10 \mathrm{~cm} \mathrm{~s}^{-1}$ behavior and diurnal $18 \mathrm{~cm} \mathrm{~s}^{-1}$ swimming for $0 \%$, $1 \%$ and $2 \%$ wind-induction. Specifically, the stage IV larvae reached mainland and island coastal populations within an average of $17 \mathrm{~d}$ (Fig. 5) in the model

Table 2. Results of a 2-way analysis of variance examining the effects of swimming and wind-induced transport on dispersal rates of Homarus americanus larvae

\begin{tabular}{lrrrrr|}
\hline Source & df & \multicolumn{1}{c}{ SS } & MS & F & p \\
\hline Swimming & 3 & 610.1895 & 203.3964 & 28.48 & $<0.01$ \\
Wind & 2 & 250.9823 & 125.4907 & 17.57 & $<0.01$ \\
Swimming $\times$ Wind & 6 & 38.8229 & 6.4705 & 0.91 & 0.4990 \\
Error & 46 & 328.5000 & 7.1413 & & \\
Total & 57 & 1228.4938 & & & \\
\hline
\end{tabular}




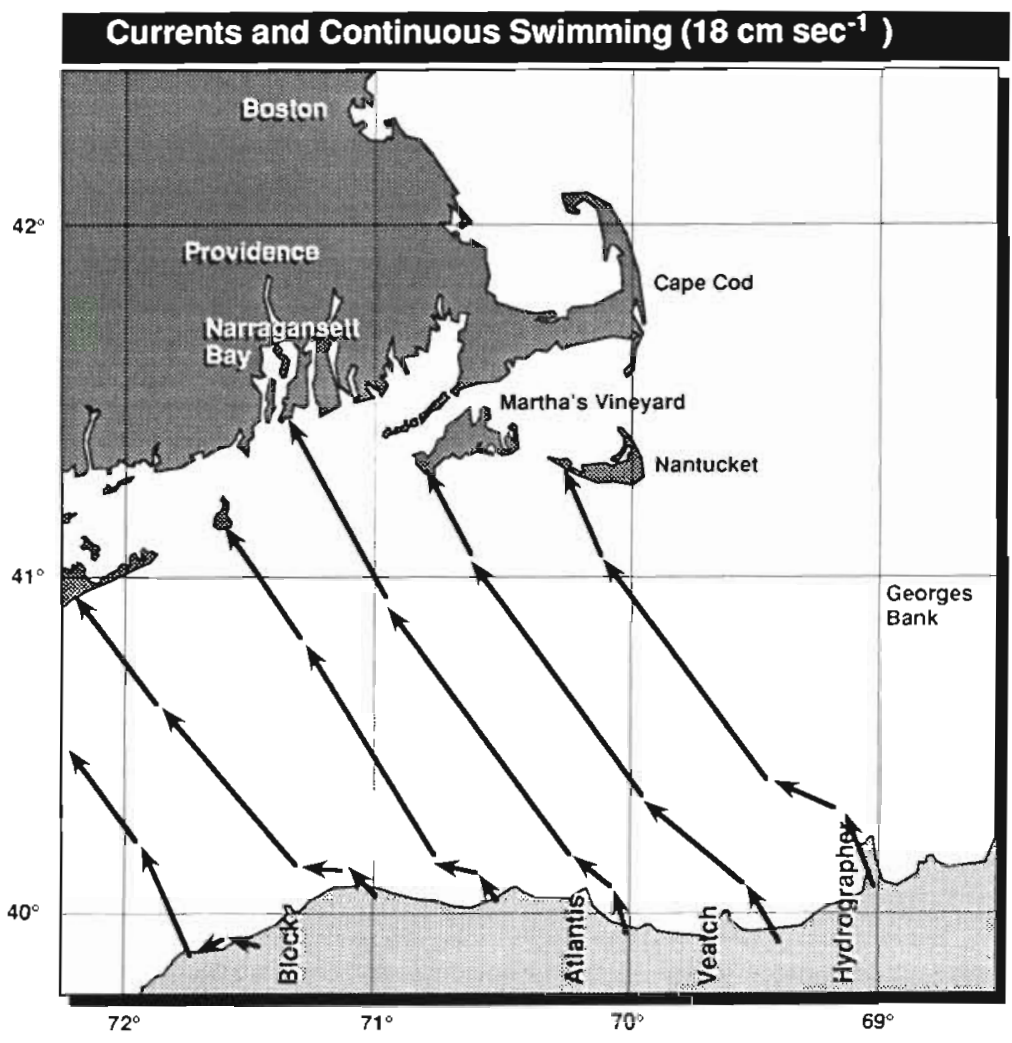

simulating surface currents and continuous swimming at $18 \mathrm{~cm} \mathrm{~s}^{-1}$. Notice that larval transport (stages I to III) during the first $10 \mathrm{~d}$ was passive and dictated by currents, while the directional swimming by the stage IV larvae traversed the majority of the distance (approximately $150 \mathrm{~km}$ ) to the coast.

Assuming diurnal stage IV larval swimming at $18 \mathrm{~cm} \mathrm{~s}^{-1}$ for $14 \mathrm{~h} \mathrm{~d}^{-1}$, offshore larvae were noted along the coast in an average of $23 \mathrm{~d}$. Transport mechanisms consisting of $1 \%$ and $2 \%$ wind-induced movement, surface currents, and diurnal swimming resulted in simulated arrival times of $20 \mathrm{~d}$ (Fig. 6) and $18 \mathrm{~d}$, respectively. Given swimming speeds of $10 \mathrm{~cm}$ $\mathrm{s}^{-1}$, offshore-inshore dispersal times were computed to range from $18 \mathrm{~d}$ with $2 \%$ wind-inducted transport and continuous swimming versus $30 \mathrm{~d}$ in the absence of wind and with diurnal swimming.

Fig. 6. Trajectories affected by currents, $1 \%$ wind-induced transport, and stage IV Homarus americanus larval swimming at $18 \mathrm{~cm} \mathrm{~s}^{-1}$ between 05:00 and 19:00 h. Arrows as in Fig. 3
Fig. 5. Simulated Homarus americanus larval dispersal as a result of surface currents and continuous stage IV larval swimming at $18 \mathrm{~cm} \mathrm{~s}^{-1}$. Arrows as in Fig. 3

\section{DISCUSSION}

The current hypotheses of larval recruitment focus on advection and diffusion processes, Ekman transport, lunar phases, and vertical migrations (Wroblewski 1982, Johnson et al, 1984, Phillips \& McWilliam 1986, Bartsch et al. 1989, Possingham \& Roughgarden 1990). For Homarus americanus, offshore larvae are thought to be transported toward the coast by surface currents (Templeman 1937, 1939, Stasko 1978, Harding et al. 1983, Ennis 1986b) and possibly by modified vertical water column movements (Caddy 1979). In general, our lobsterlarvae dispersal model suggests that surface currents and wind-induced transport in and of themselves are insufficient conditions for successful offshore recruitment subsidies to coastal populations in south-

\section{Currents, Wind (1\%), and Diurnal Swimming (18 $\mathrm{cm} \mathrm{sec}^{-1}$ )}

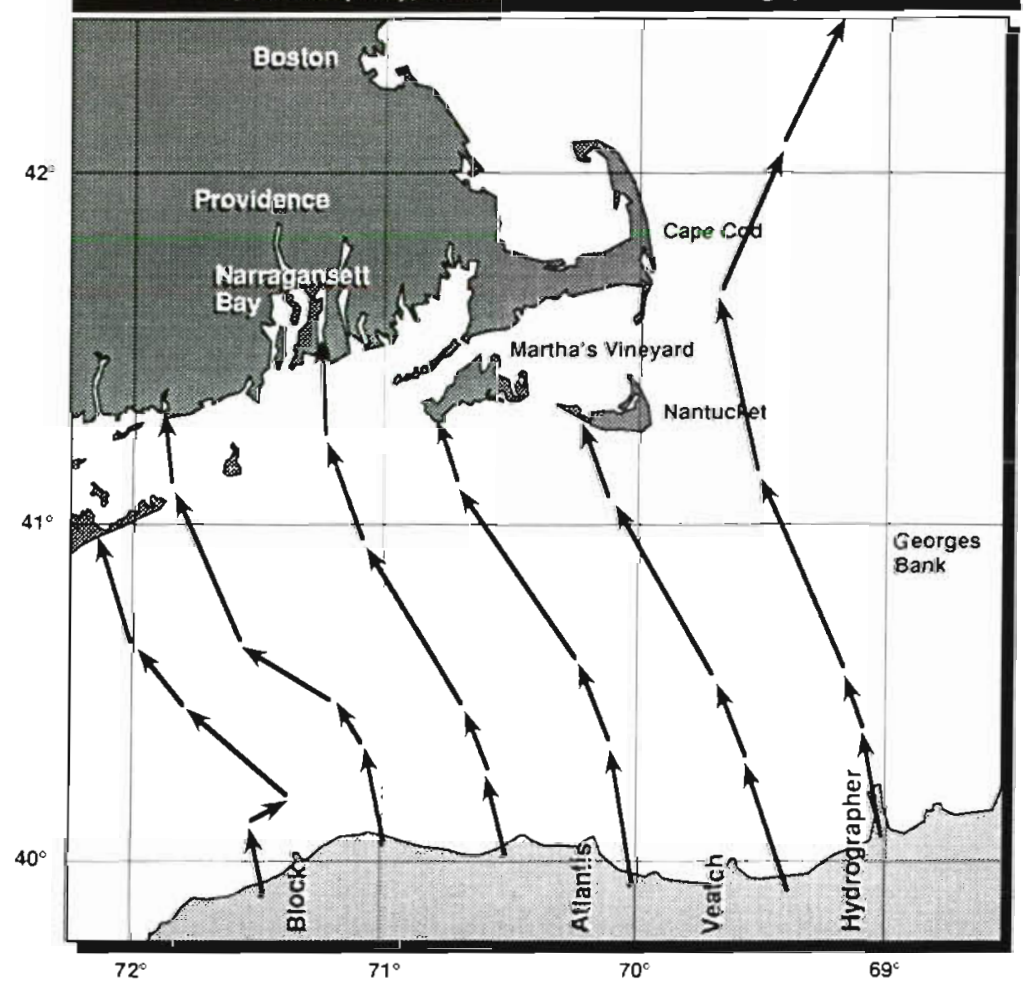


ern New England. Passive drift of the larvae reveals dispersal patterns that do not overlap with coastal habitats. Instead, drifting larvae would be transported to the southwest by the prevailing surface currents on the southern New England shelf. The integration of wind-induced movement with surface currents produces larval trajectories that intersect with the islands off the coast after $40 \mathrm{~d}$. In order for these 2 physical oceanographic factors to actually serve as a mode of dispersal, the planktonic and pelagic stages of $H$. americanus would need to be delayed by approximately $2 \mathrm{wk}$ assuming that the average developmental time is $26 \mathrm{~d}$. In contrast, strong directional swimming of the stage IV larvae results in recruitment to coastal populations within the duration of the planktonic/pelagic phase. Continuous and diurnal swimming at $18 \mathrm{~cm} \mathrm{~s}^{-1}$ contributes to the traversing of the continental shelf within a range of 17 to $23 \mathrm{~d}$. If the settlement to the benthos occurs halfway through the fourth larval stage as suggested by Scarratt (1973), then the number of days the larvae spend in the water column would be further constrained. For a larval phase of $18 \mathrm{~d}$, potential dispersal mechanisms would be limited to continuous swimming at $18 \mathrm{~cm} \mathrm{~s}^{-1}$ or diurnal swimming $\left(18 \mathrm{~cm} \mathrm{~s}^{-1}\right)$ with $2 \%$ wind-induced transport.

Several general insights concerning the mechanisms of larval recruitment can be generated from the simulations of the trajectory model. First, several authors have hypothesized that fourth stage larval swimming may be an important behavioral trait for selecting suitable benthic habitats during colonization (Ennis 1986b, Hudon et al. 1986, Cobb et al. 1989). Our field evidence and model imply that directional swimming could also be a key mechanism for long distance regional lobster larval dispersal. Second, increases in larval phase duration or reductions in larval swimming speed as a result of environmental factors (e.g. poor nutrition, cooler water temperatures) would increase the significance of wind-induced transport. The mosaic of transport mechanisms affecting successful larval dispersal to coastal habitats, therefore, could vary depending on the yearly fluctuations of biological and physical conditions. Lastly, the migrations of mature adults between coastal and offshore habitats provides another mechanism of population interdependency. Inshore migrations from the outer continental shelf during the spring (Cooper \& Uzmann 1971) could lead to the direct transfer of eggs by benthic adult transport, or young could be released at some intermediate distance on the continental shelf to augment hydrodynamic and behavioral dispersal processes.

The overall conclusions from our field evidence and dispersal model pose important implications for the regional population dynamics and management of Homarus americanus. If lobsters in the canyons act as regional donors of larvae larval, then these recruitment subsidies would tend to buffer local coastal populations from over-exploitation. Conversely, if the offshore populations are heavily harvested and recruitment subsidies are diminished, then regional reductions in the lobster population would become more likely. Our future endeavors will be to experimentally evaluate the mechanisms of larval dispersal on the northeast continental shelf, and attempt to ascertain the percent contribution of larvae from offshore to coastal populations.

Acknowledgements. We thank Robert Sand and Steve Cieslick for their support at the Graduate School of Oceanography's Computer Center. Annette Juinio gathered the data for Fig. 1. We express our sincere appreciation to Scott Nixon and the University of Rhode Island Sea Grant Program for the research funds for this project (Project \# MPD-8908).

\section{LITERATURE CITED}

Ambrose, W. G. Jr (1984). Role of predatory infauna in structuring marine soft-bottom communities. Mar. Ecol. Prog. Ser. 17: 109-115

Bartsch, J., Brander, K., Heath, M., Munk, P., Richardson, K., Svendsen, E. (1989). Modelling the advection of herring larvae in the North Sea. Nature 340:632-636

Beardsley, R. C., Boicourt, W. C., Hansen, D. V (1976). Physical oceanography of the Middle Atlantic Bight. In: Gross, M. G. (ed.) Proceedings of the symposium Middle Atlantic continental shelf and the New York Bight. American Museum of Natural History, New York, p. 3-5

Black, K. P., Morgan, P. J. (1991). Influence of hydrodynamics on the passive dispersal and initial recruitment of larvae of Acanthaster planci (Echinodermata: Asteroides) on the Great Barrier Reef. Mar. Ecol. Prog. Ser. 69: 55-65

Bumpus, D. F., Lauzier, L. M. (1965). Surface circulation on the continental shelf off eastern north Atlantic between Newfoundland and Florida. In: Webster, W. (ed.) Serial atlas of marine environments, Folio 7. American Geographic Society, New York

Caddy, J. F. (1979). The influence of variations in the seasonal temperature regime on the survival of the larval stages of the American lobster (Homarus americanus) in the southern Gulf of St. Lawrence. Rapp. P.-v. Réun. Cons. int Explor, Mer 175: 204-216

Caffey, H. M. (1985). Spatial and temporal variation in the settlement and recruitment of intertidal barnacles. Ecol Monogr. 55: 313-332

Caswell, H. (1978). Predator-mediated coexistence: a nonequilibrium model. Am. Nat. 112: 127-154

Cobb, J. S., Wang, D., Campbell, D, B., Rooney, P. (1989) Speed and direction of swimming by postlarvae of the American lobster. Trans. Am. Fish. Soc. 118: 82-86

Connell, J. H. (1961). The influence of interspecific competition and other factors on the distribution of the barnacle Chthamalus stellatus. Ecology 42: 710-723

Cooper, R. A., Uzmann, J. R. (1971). Migrations of deep-sea lobsters, Homarus americanus. Science 171: 288-290

Davis, C. S. (1984). Interaction of a copepod population with a 
mean circulation of Georges Bank. J. mar. Res. 42: $573-590$

Dayton, P. K. (1971). Competition, disturbance, and community organization: the provision and subsequent utilization of space in a rocky intertidal community. Ecol. Monogr. 41. $351-389$

Ennis, G. P. (1986a). Stock definition, recruitment variability, and larval recruitment processes in the American lobster, Homarus americanus: a review. Can. J. Fish. Aquat. Sci. 43: $2072-2084$

Ennis, G. P. (1986b). Swimming ability of the larval American lobster, Homarus americanus, in flowing water. Can. J. Fish. Aquat. Sci. 43: 2177-2183

Epifanio, C. E., Valenti, C. C., Pembroke, A. E. (1984). Dispersal and recruitment of blue crab larvae in Delaware Bay, USA. Estuar. coast. Shelf. Sci. 18: 1-12

Gaines, S., Roughgarden, J. (1985). Larval settlement rate: a leading determinant of structure in an ecological community of the marine intertidal zone. Proc. natl Acad. Sci. U.S.A. 82: $3707-3711$

Gilhousen, D. B., Quayle, R. G., Baldwin, R. G., Karl, J. R., Brines, A. (1983). Climatic summaries for NOAA data buoys. NOAA Buoy Center NSTL Station, Pascagoula, MS

Godshell, F., Williams, R, Bishop, J., Everdale, F., Fehier, S. (1980). A climatologic and oceanographic analysis of the Georges Bank region of the outer continental shelf. NOAA Center for Environmental Assessment Services, Washington, $\mathrm{DC}$

Harding, G. C., Drinkwater, K. F., Vass, W. P. (1983). Factors influencing the size of the American lobster (Homarus americanus) stocks along the Atlantic coast of Nova Scotia, Gulf of St. Lawrence and the Gulf of Maine: a new synthesis. Can. J. Fish. Aquat. Sci. 40: 168-184

Harding, G. C., Pringle, J. D., Vass, W. P., Pearre, S. Jr, Smith, J. S (1987). Vertical distribution and daily movements of larval lobsters Homarus americanus over Browns Bank, Nova Scotia. Mar. Ecol. Prog. Ser 41:2 9-46

Herrick, F. H. (1909). Natural history of the American lobster. Bull. Bur. Fish., Wash. 29: 149-408

Holbrock, S. J., Schmitt, R. J. (1989). Resource overlap, prey dynamics and the strength of competition. Ecology 70: 1943-1953

Hudon C., Fradette, P., Legendre, P. (1986). La repartition horizontale et verticale des larvaes de homard (Homarus americanus) autour des iles de la Madeleine, golfe du Saint-Laurent. Can. J. Fish. Aquat. Sci. 43: 2164-2176

Hughes, T P. (1990). Recruitment limitation, mortality, and population regulation in open systems: a case study. Ecology 71: 12-20

Jackson, G. A., Strathmann, R. R. (1981). Larval mortality from offshore mixing as a link between precompetent and competent periods of development. Am. Nat. 118: 16-26

Johnson, D. R., Hester, B. S., McConaugha, J. R. (1984). Studies of a wind mechanism influencing the recruitment of blue crabs in the middle of the Atlantic bight. Cont. Shelf Res. 3: 425-437

Jones, G. P. (1987). Competition among adult and juveniles in a coral reef fish. Ecology 68: 1534-1547

Katz, C. H. (1985). A nonequilibrium marine predator-prey interaction. Ecology 66: 1426-1438

Keough, M. J. (1983). Patterns of recruitment of sessile invertebrates in two subtidal habitats. J. exp. mar. Biol. Ecol. 66: $213-245$

Keough, M. J. (1984). Dynamics of the epifauna of the bivalve Pinna bicolor interactions among recruitment, predation, and competition. Ecology 65: 667-688
Loosanoff, V. L. (1964). Variations in the time and intensity of settling of the starfish. Asterias forbesi, in Long Island Sound during a 25 year period. Biol. Bull. 126: 423-439

Lough, R. G. (1976). Larval dynamics of the Dungeoness crab, Cancer magister, off the central Oregon coast 1970-1976. Fish. Bull. U.S. 74: 353-375

Ortega, S. (1986). Fish predation on gastropods on the Pacific coast of Costa Rica. J. exp. mar. Biol. Ecol. 97: 181-191

Paine, R. T (1966). Food web complexity and species diversity. Am. Nat. 100:65-75

Phillips, B. F., McWilliam, P. S. (1986). The pelagic phase of spiny lobster development. Can. J. Fish. Aquat. Sci. 43: $2153-2163$

Possingham, H. P., Roughgarden, J. (1990). Spatial population dynamics of a marine organism with a complex life cycle. Ecology 71: 973-985

Robertson, R. (1964). Dispersal and wastage of larvae Philippia krebsii (Gastropoda. Architectonicidae) in the North Atlantic. Proc. Acad nat. Sci. Philad. 116: 1-27

Rooney, P. (1988). Swimming behavior of the postlarval lobster, Homarus americanus. M.Sc. thesis, University of Rhode Island, Kingston

Rooney, P., Cobb, J. S. (1991). Effects of time of day, water temperature and water velocity on swimming by postlarvae of the American lobster, Homarus americanus. Can. J. Fish. Aquat. Sci. 48: 1944-1950

Roughgarden, J., Gaines, S., Possingham, H. (1988). Recruitment dynamics in complex life cycles. Science 241 : $1460-1466$

Roughgarden, J. D., Iwasa, Y., Baxter, C. (1985). Demographic theory for an open marine population with space limited recruitment. Ecology 66: 54-57

Sale, P. F. (1978). Coexistence of coral reef fishes - a lottery for space. Envir. Biol. Fish. 3: 85-102

SAS (1985). SAS user's guide: statistics, version 5 edn. SAS Institute, Inc., Cary, NC

SAS (1987). SAS guide for personal computers, version 6 edn SAS Institute, Inc., Cary, NC

Scarratt, D. J. (1973). Abundance, survival, and vertical and diurnal distribution of lobster larvae in the Northumberland Strait, 1962-1963 and their relationship with commercial stocks. J. Fish. Res. Bd Can. 24: 1819-1824

Scheltema, R. S. (1964). Origin and dispersal of invertebrate larvae in the North Atlantic. Am. Zool. 4: 299-300

Scheltema, R. S. (1966). Evidence of trans-Atlantic transport of gastropod larvae belonging to the genus Cymatium. Deep Sea Res. 13: 83-95

Scheltema, R. S. (1968). Dispersal of larvae by equatorial currents and its importance to the zoogeography of shoalwater tropical species. Nature 217: 1159-1162

Scheltema, R. S. (1971). Larval dispersal as a means of genetic exchange between geographically separated populations of shallow water benthic marine gastropods. Biol. Bull. 140: $284-322$

Scheltema, R. S. (1986). On the dispersal and planktonic larvae of benthic invertebrates: an eclectic overview and summary of problems. Bull. mar. Sci. 39: 290-322

Spaulding, M. L. (1988). A state-of-art of oil spill trajectory modeling. Oil Chem. Pollut. 4: 39-55

Stasko, A. B. (1978). Inshore-of fshore SW Nova Scotia lobster stock interactions: an hypothesis. CAFSAC Res. Doc $78 / 37$

Stolzenbach, K. D., Madsen, O. S., Adams, E. E., Pollack. A. M., Cooper, C. K. (1977). A review and evaluation of basic techniques for predicting the behavior of surface oil slicks. MIT Sea Grant Program Report No. MITSG77-8, Cambridge 
Strathmann, R. R. (1985). Feeding and non-feeding larval development and life history evolution in marine invertebrates. A. Rev. Ecol. Syst. 16: 339-361

Sutherland, J. P. (1990). Recruitment regulated demographic variation in a tropical intertidal barnacle. Ecology 71 $955-972$

Templeman, W. (1936). The influence of temperature, salinity, light and food conditions on the survival and growth of the larvae of the lobster (Homarus americanus). J. biol. Bd Can. 3: 485-497

Templeman, W. (1937). Habits and distribution of larval lobsters (Homarus americanus). J. biol. Bd Can. 3: 343-347

Templeman, W. (1939). Investigations into the life-history of the lobster (Homarus americanus) on the west coast of Newfoundland, 1938. Newfoundland Dept Nat. Res. Bull. (Fish) 7, St. John's

Thorson, G. (1950). Reproductive and larval ecology of marine invertebrates. Biol. Rev. 25: 1-45

Thorson, G. (1961). Length of pelagic life in marine invertebrates as related to larval transport by ocean currents. In: Sears, M. (ed.) Oceanography. Publ. 67, American Association for the Advancement of Science,

This article was submitted to the editor
Washington, DC, p. 455-474

Thorson, G. (1966). Some factors influencing the development and establishment of marine benthos communities. Neth. J. Sea Res. 3: 267-293

Wahle, R. Steneck, R. S. (1991). Recruitment habitats and nursery grounds of the American lobster Homarus americanus: a demographic bottleneck? Mar. Ecol. Prog. Ser. 69: $231-243$

Wallace, A. D. (1876). The geographic distribution of animals, Vol. 1. Harper's Publishing Co., New York

Wilder, D. G. (1953). The growth rate of the American lobster (Homarus americanus). J. Fish. Res. Bd Can. 10: 371-404

Wroblewski, J. S. (1982). Interaction of currents and vertical migration in maintaining Calanus marshallae in the Oregon upwelling zone - a simulation. Deep Sea Res. 29: $665-686$

Underwood, A. J., Denley, E. (1984). Paradigms, explanations, and generalizations in models for the structure of intertidal communities on rocky shores. In: Strong, D., Simberloff, D., Abele, L., Thistle, A. (eds.) Ecological communities: conceptual issues and the evidence. Princeton University Press, Princeton, p. 151-180

Manuscript first received: December 11, 1991

Revised version accepted: June 13, 1993 